\title{
Affirmation of the Social Approach in the Case of Relocation of Community in Ciliwung Riverbank
}

Komunitas: International Journal of Indonesian Society and Culture 11(2) (2019): 195-206

DOI:10.15294/komunitas. v11i2.18123

(C) 2019 Semarang State University, Indonesia p-ISSN 2086 - 5465 | e-ISSN 2460-7320 http://journal.unnes.ac.id/nju/index.php/komunitas

\section{Prudensius Maring ${ }^{1}$ and Elisabeth Endang Prakosawati ${ }^{2}$}

${ }^{1}$ Faculty of Communication Sciences, University of Budi Luhur, Jakarta

${ }^{2}$ Sekolah Tinggi Teknologi Kedirgantaraan, Yogyakarta

Received: February 14, 2019; Accepted: September 1, 2019; Published: September 30, 2019

\begin{abstract}
Urban development projects often lead to social contraction between the technical-physical approach and the socio-cultural approach. To explain the problem, this paper inspires the concepts of urban anthropology and socio-cultural development. The study was conducted in 2016-2017 in community located in Ciliwung riverbank, Jakarta. The methods used include in-depth interviews, participatory observations, and document analysis. The results of the study show that although river normalization projects and relocation projects have been equipped with a policy framework and technical framework that accommodates the interests of the community, the implementation of the social approach has not been implemented consistently. This condition raises doubts, rejections, and resistance from the community to maintain the social, economic and environmental resources that have been ruled on the riverbanks. This research confirms the importance of affirming socio-cultural approaches in urban development programs and projects that are carried out consistently by fulfilling the prerequisites for freedom in time, financing, and management resources.
\end{abstract}

\section{Keywords}

Ciliwung River; riverbanks; normalization; relocation; urban communities; socio-cultural approache

\section{INTRODUCTION}

Inequality in rural and urban development can be seen from the large flow of urbanization. The limitation of employment in the countryside and the expectation of working in urban areas has led to population movements from rural to urban areas. The rate of population movement from rural to urban areas in Indonesia is the fastest in Asia. Over the past 60 years, the urban population in Indonesia has increased by an average of $4.4 \%$. Now there are around 177 million people living in urban areas. The high population movement from rural to urban areas does not necessarily increase the economic level of the population in such area (World Bank 2016). As a result of the low level of education and skills, the most potential absorption of labor from the countryside is to become factory workers, construction workers, and work in the informal sector with low wages. However, urban life requires the role of informal sector workers so that high urban living costs can be reached by the

\footnotetext{
Corresponding author

Jl. Raya Ciledug, Petukangan Utara

Jakarta Selatan 12260

Email

prudensiusmaring9@gmail.com
} 
middle class.

The density of the urban population also has implications for the high pressure on the use of urban space such as residential areas, public open spaces, green open spaces, and public facilities to improve the quality of people's welfare. Dense urban populations and urban governance failures in Southeast Asia have given rise to poor villages and wild huts which are inhabited by around $37 \%$ of urban population (Taylor 1993). This phenomenon is strengthened by the description of the structure of the livelihoods of urban residents who are predominantly sourced from the informal sector due to the low knowledge and skills of the urbanized population. Hans-Dieter Evers described groups of people who came from rural to urban areas with low skills as floating masses in cities that were economically and socially vulnerable because livelihoods were easily shifted (Hans-Dieter Evers 1993).

In the long run, this condition gave birth to many social problems. Urban area development managers tend to build perceptions that position urban society as a source of problems (Taylor 1993). The community is considered to endanger health, the source of crime (crime, delinquency, extortion), and the destruction of the image of the urban area that needs to be returned to the village. The general attitude of the government is reminiscent of Hans-Dieter Evers's view that from the outset there was a distortion of perspective in which urban problems were seen as the impact of over-urbanization not as an under-development urban problem (Hans-Dieter Evers 1993). This perspective is followed by urban structuring actions in the form of relocation, eviction and expulsion programs. This method shows the failure to understand the root causes of urban development problems. Such actions give rise to resistance and public rejection of urban planning efforts.

Since the beginning of independence, the destination location intended by villagers who have come to Jakarta is a location close to physical projects where they become laborers. Other locations are areas that are not economically targeted for city develop- ment which are areas seen as suburban areas that are easily controlled by them since such areas are not controlled by the government. In this process, 13 riverbanks which flow in the Jakarta area are targeted by the community to be used as residential land. 71,00o households are registered in the riverbank area in Jakarta. Riverbanks are a resource that serves the socio-economic needs of the community. Riverbank communities develop socio-economic adaptation strategies, strengthen livelihood sources and social organizations ( Tim Ekspedisi Ciliwung Kompas 2009; Maring et al. 2015c).

The intensity of utilization of riverbanks has caused flooding which has affected environmental damage and economic losses. In a wider scope, flooding is the most destructive natural disaster and has a negative impact that has been widespread in the world in the past few decades. Based on broad-scale analysis in several countries, Mard, et al. (2018) stated that in the period 1980 to 2014 floods caused losses of around US\$ 1 trillion and caused human casualties of around 226,00o. The widespread loss due to widespread flooding illustrates more and more residents and assets they have in areas prone to flooding. In the future, the impact of floods depends largely on the way the community adapts sustainably, how to respond, and the risk management approach that is applied. Various choices can be made such as flood control, early warning systems, relocation, and permanent migration (Mard, et al. 2018).

The series of major floods of the Ciliwung River in the past two decades has prompted the government to run dredging projects of rivers, reservoirs and canals due to siltation known as the Jakarta Urgent Flood Mitigation Project (JUFMP). In addition, the river normalization project was carried out with a focus on structuring the Ciliwung riverbank. The implementation of these physical projects received support and rejection from the community. The pros and cons that occur are mainly because these projects have implications for the relocation of urban settlements. Relocation of residents is carried out through resettle- 
ment projects. Although the project refers to the resettlement policy framework (RPF), however the implementation of the project leaves the problem of the approach, both at pre-relocation and post-relocation (Mikmah 2010; Siswanto 2014).

The above problem also occurs elsewhere. The results of a resettlement relocation project study in Bangkok show that there are a number of preconditions for achieving success, both internal and external factors. The choice of a new settlement location that is in accordance with the interests of the community and compensation for the population is an external factor that determines success. The important internal factor to consider is the presence of unity, strong leadership, active participation and positive behavior from community members. The relocation project must take a special approach to the consolidation phase, the resettlement phase, and the transition phase (Viratkapan and Perera 2004). This particular approach needs to be carried out because the project of moving the population of the city does not only have implications for the loss of population land, but also has social implications. As in the case of resettlement in the construction of the city of Sarawak, in addition to losing land, the community also lost social structure, social life energy, traditional processes of people's lives, and lost economic resources (Ahsan and Ahmad 2016).

To understand the reality of complex urban life, this analysis inspires urban anthropological approaches (Suparlan 2004). The urban anthropological approach interpret urban from two perspectives, namely urban with problems that exist within themselves, and urban with broader contexts that explain the problems that exist in urban life. The perspective of urban anthropology is important to overcome the perspective of urban development managers who often see urban problems as a result of urbanization. The perspective of urban anthropology can provide a qualitative approach to urban problems. The progress urban area is not only seen from physical and economic achievements. The target of urban anthropology studies is directed at community culture, social institutions that live and develop in the urban area. The main studies on culture and social institutions are seen in daily life, patterns of action, community life, economics, relations between ethnic groups or ethnicities, social groups, hierarchies and social stratification, poverty, and the slums of settlements (Suparlan 2004).

The view of urban anthropology is in line with the socio-cultural development approach. Wirutomo (2014) stated that urban development must touch structural elements, cultural elements, and processual elements. Structural elements are reflected in balanced, strict and effective legislation. Development actors are not sufficiently protected behind a rigid and unresponsive policy. Structural strength is needed that is able to regulate, force and limit the actions of the community. The structural framework must rest on cultural elements that develop in people's lives. Cultural elements relate to the integration of values and norms, traditions, awareness, perceptions, and ways of thinking of society. The two elements above must be developed in a dynamic and open processual element. Processual elements are informal interaction spaces, dynamic and creative negotiation processes. Therefore, the processual element becomes a dynamic medium to maintain structure and culture.

The problem being analyzed in this paper is how to integrate the socio-cultural approach to urban development projects that have technical-physical characteristics. River normalization and population relocation are interrelated projects and have been supported by a policy framework and technical framework that accommodate physical and social instrument prerequisites. But in its implementation, the sociocultural approach has not been fully implemented. In fact, riverbank normalization projects take place on land and settlements that have been controlled by the community through a long process of social, economic and environmental adaptation. The relocation project is related to changes in the socio-economic strategy that will be carried out by post-relocation communities. 


\section{METHODS}

In order understanding the complexity of urban problems, this study uses a qualitative approach. Several methods are used for data collection, namely in-depth interviews, participatory observations, focus group interviews (Creswell 2010; Creswell 2013). The method is applied simultaneously and flexibly according to the needs and types of data. Data collected includes primary data, secondary data, and policy documents needed in this study. In-depth interviews and participatory observations are carried out informally by involving the community. Focus group interviews were conducted through group meetings to find out community perceptions and the collective experience of the community regarding settlements, flood impacts, river normalization projects and relocation projects in the form of flats.

The data used in this article comes from field research in 2016-2017. The funding sources for the research come from the grant schemes of the Ministry of Research, Technology and Higher Education. Primary data sources mainly relate to socio-economic strategies and community strategy data in response to the government's approach and project apparatus. Primary data is obtained through interviews and observations. Data on normalization and relocation projects mainly come from secondary documents and research results. Other data sources come from the recording and recording of mass media coverage. The informants in this study were the communities on the riverbank of Ciliwung at the research site. Some of them are community members, neighborhood administrators, community leaders, and religious leaders in the region. Government officials at sub-district level also became informants in this study.

This research was conducted on communities on the riverbank of Ciliwung, especially in Cawang, Kampung Melayu, and its surroundings. Administratively, the location is in the East Jakarta area. The number of residents of Kampung Melayu sub-district who live along the riverbank of Ciliwung is
7,233 households. The number of residents of Cawang sub-district who live along the riverbank of Ciliwung is 1,623 households. In the context of the wider region, the number of Jakarta residents living along the riverbank of Ciliwung is around 34,051 households. The amount is spread along the riverbank of Ciliwung in 13 areas of subdistricts. This amount contributes to around 71,000 households living on 13 riverbanks and reservoirs in Jakarta. Some communities on the riverbank of Ciliwung work in the informal sector. In limited numbers of community work in the formal sector such as offices. Some settlements on the riverbank of $\mathrm{Ci}$ liwung have poor basic infrastructure (Tim Ekspedisi Ciliwung Kompas 2009; Maring, et al. 2015b; Gazali 2014; Siswanto 2014)

\section{RESULTS AND DISCUSSION}

This section discusses two things, first about structural dilemmas and social contractions, second about affirming social approaches. River normalization projects and resettlement relocation projects carried out in the community continue to strengthen their social and economic strategies on the riverbanks. In this situation, the entry points for programs and urban development projects should utilize social structures and social processes that are run by the community. In fact, the implementation of the project, despite being equipped with a policy framework and technical framework, turned out to be less responsive to the dynamics that developed in the community. As a result, even though the project continues but there is a social contraction in the life of the riverbank community. There was resistance and public rejection of river normalization projects and relocation projects since the precondition phase, relocation phase, and post-relocation. Based on these conditions, it was also discussed about the affirmation of the socio-cultural approach that was applied consistently in the precondition phase, the relocation phase, and the post-relocation phase of the community. 


\section{Structural dilemmas and social con- traction}

Floods with a large impact since the 2000 s have prompted the government to manage 13 riverbanks, reservoirs and situ in the Jakarta area. First, the dredging project of rivers, reservoirs and canals due to siltation known as the Jakarta Urgent Flood Mitigation Project (JUFMP). Second, the Ciliwung river normalization project which focuses on structuring the riverbank of Ciliwung. The two projects were started around 2012. The technical-physical activity of river normalization was river dredging, river widening along the 50 meters left and right of the river, concrete sheet making, and the $7.5^{-m e-}$ ter-wide right-left river inspection road. The program slipped hopes of overcoming the problems of settlements and the socioeconomic life of the communities along the rivers, reservoirs and situ. The program was implemented through the concept of "building settlements without slums and building flats to relocate affected riverbanks. The development of row villages ("kampung deret") is one of the breakthroughs to improve slum settlements and alleviate poor people in poorly identified villages (Mikmah 2010; Siswanto 2014).

River normalization in line with resettlement arrangement projects. This project refers to the resettlement policy framework (RPF). The framework gives hope to the community because it stipulates that the resettlement process must ensure that the people affected by the project cannot be worse off after the project. The relocation project must involve the government, the community, NGOs and Legal Aid Institution in the process of designing a suitable relocation project. Relocation must compensate land and buildings, find solutions to economic activities of affected people, provide settlements, and rebuild public facilities in new settlements. In the broader framework, the river normalization project and relocation are part of the spatial planning of DKI Jakarta Province which is regulated through the Regional Regulation of DKI Jakarta No. 1 of 2012 concerning the Jakarta Spatial Planning for 2030 and the DKI Jakarta Re- gional Regulation No. 1 of 2014 concerning Detailed Spatial Planning and Zoning Regulations (BPDAS Citarum-Ciliwung 2009; Pemda DKI Jakarta 2010; Ali 2014).

Within the policy framework and technical framework, it is stated that the management of the Ciliwung river basin must accommodate the existence of the community through social mapping activities, need assessment, social education, and community facilitator involvement. The involvement of stakeholders is carried out widely, including the DKI Jakarta Government as the executor, the Ministry of Public Housing as a provider of residential facilities, the Ministry of Social Affairs to overcome social impacts, the Ministry of Forestry handles technical watershed arrangement, and the Ministry of Public Works coordinates the entire program. Outside the government agencies, it is regulated about the role of the community, NGOs, Legal Aid Institutions, social workers, assistants and extension agents. This description shows that the policy framework contains directions and work instruments that care about the interests of the community. It is seen that the aspects of the socio-economic life of the community are getting attention (Mikmah 2010; BPDAS Citarum-Ciliwung 2009).

Based on the results of the initial survey after routine flooding since the 20oos, it is known that the community on the riverbank of Ciliwung is ready to move to a new residential location not far from the $\mathrm{Ci}^{-}$ liwung river. Since 2011 the discussion on the construction of flats has been intensified. In 2012 the DKI Jakarta Government focused on data collection on affected residents and mentoring. Flats are seen as the right choice for riverbank residents, although in some cases the flats are not only inhabited by target groups, such as flats in Tanah Abang, Kebun Kacang, Tebet, and Penjaringan. Since 2013 until 2016, the DKI Jakarta Government has significantly realized the normalization of the Ciliwung river and transferred residents to flats from the riverbanks in Kampung Pulo and Bukit Duri to Jatinegara, Cipinang Besar Selatan, and Pulogebang flats.

The description above shows that 
programs and projects have been carefully prepared. Behind the normalization and relocation projects that are equipped with a policy framework and technical framework, a number of questions arise: Are the project implementations following the social preparation framework that relates to the community? Does the normalization and relocation project refer to the socio-economic conditions of the community? Have collected socio-economic data been used in implementation? Studying various social constructs in the form of rejection, resistance, and acts of violence that occur, it seems that the policy framework, framework, and social instruments have not been fully implemented. Social processes lose quickly with physical-technical processes with measurable and budget-based project time targets. The execution of technical implementation cannot wait for a social process that must adjust to the social dynamics of the community. The physical-technical process is faster than social processes in the field.

This study shows that during 2016 to 2017 two projects with a technical-physical character were competing to meet the target time. River normalization projects and the construction of flats are seen pursuing physically measurable targets, time and budget. It seems that there is no tolerance to wait for a slow social process and is difficult to ascertain in terms of time. In fact, the rapid movements of the two projects were to serve the needs of the community. The direction of the river normalization project that encourages people to quickly get out of the riverbanks, must be responded to and welcomed by the project to build flats to provide housing for residents who come out from the riverbanks. In an effort to achieve the technical-physical target, the language sent to the community is a "warning letter". Affected residents who remain on the riverbank are warned to immediately exit the riverbank before execution in the form of forcibly demolishing homes or other facilities through ordinary machine work called heavy equipment ("alat berat").

This study shows that the strength of the project approach language pursued by targets is "deadlines". The language of the deadline is realized through a warning letter 1, warning letter 2, warning letter 3, and subsequently a demolition warrant to the day of " $D$ " of execution. In that situation, the presence of a warning letter made the field situation messy, the people were overwhelmed, and finally gave up. The deadline language always limits people's movement because warning letter 1 tolerates $7 \mathrm{x}$ 24 hours, warning letter 2 tolerates $3 \times 24$ hours, and warning letter 3 tolerates $1 \times 24$ hours. If warning letter 3 is not fulfilled, the demolition warrant will be issued. In fact, at the field level there is a diversity of status in the control of resources and sources of livelihood for the community. The impact of the above approach can be seen in the form of resistance and public rejection in some locations of riverbank normalization, such as the refusal of cases of land acquisition of the Ciliwung river in Kampung Melayu and Bukit Duri. In Bukit Duri, the community also took legal action to sue the land execution decision (Maring et al. 2015b). Social contractions erupted at several points of settlement in the form of resistance and violence on the riverbanks that were targeted by the project.

Social contraction in the form of citizen doubts, anxiousness, waiting in anxiety, protests for resettlement, demonstrations demanding compensation, and incidents of physical violence in several locations normalizing the riverbank of Ciliwung show that there are problems with social approaches. Projects like being trapped in the rush to realize technical-physical targets. The community complained that until the execution of the project there had been no intensive, in-depth and effective socialization from the government regarding community social preparation. Communities on the riverbanks are still nervous about relocation information, asset compensation opportunities, and business opportunities in new places. In fact, the framework of stakeholders has been regulated in the framework of community assistance. In certain places, such as in Cawang, the community claims to be resigned to things that will happen. 
This situation is complex because information about river normalization activities is widespread in various print and electronic media. Information about the execution of physical activities is widespread without control and seems confusing. All that adds to people's anxiety.

On the other hand, the presence of apparatus at the field level is more played by officials who come to the community for the purpose of enforcing rules and executing physical-physical activities. Government orders in the form of "warning letter 1, warning letter 2, warning letter 3 ", until the time for execution is an event that remains in people's memories. When the execution time of technical-physical activities arrives, negotiations cannot occur because what the community faces is heavy equipment ("alat berat") that is controlled by operators that cannot be negotiated. When the normalization process took place, the people in Cawang stated that they did not inhibit the normalization of the river, but they needed persuasive preparation. The community stated that they were ready to follow the settlement scheme. Even proactively the settlement scheme choices have been deliberated at the neighborhood level and community groups. The description of the situation is in line with Lipsky's view that the public service dilemma always occurs when dealing with officials at the field level who only carry out orders (Lipsky 1980).

The community complains about the absence of the role of facilitators, extension workers and social workers as stated in the river normalization framework and resettlement framework. The project and its implications have not been widely and deeply disseminated to the community. In fact, in conditions where the community has experienced a long process of socio-economic adaptation along the riverbank, a social approach that is truly and more patient should be applied. The process of moving residents from the riverbanks must avoid the rush because the process is not merely a physical location change. Relocation is not only related to housing, but also related to social processes (re-social). Relocation requires a process of preparation to move and preparation for adaptation. Moving preparations relate to the readiness to relinquish relationships and socio-economic activities that have been built before. Adaptation preparation is related to readiness to build relationships and socio-economic activities in new places. The importance of social preparation in community relocation from the Ciliwung riverbank is also in line with what was stated by Viratkapan and Perera (2004) about relocation cases in Bangkok and stated by Ahsan and Ahmad (2016) about relocation cases in Sarawak.

\section{Affirmation of social approaches}

The description above shows the need to overcome the dilemma of the urban development approach that is strong in the technical-physical orientation but weak in terms of the social approach. Here two things need to be discussed. First, how to overcome the urban development gap by maintaining the balance of structural elements, cultural elements and processual elements. The development of riverbank communities must be able to maintain a balance between the technical-physical approach and the social approach. This is important to be discussed because urban development often places social approaches as a secondary problem. Second, how to overcome the gap by strengthening sustainable change management strategies. River normalization and relocation programs must be seen as the realization of the vision of urban development by placing the community as a central point.

Affirmation of the importance of social approaches in urban development is the effort to put humans as the subject and orientation of development. The social approach is not merely an administrative and procedural fulfillment. As described above, in each policy framework and implementation of technical-physical projects, a social approach has been arranged, but not fully implemented in the field. In accordance with the framework, the role of stakeholders should be carried out effectively at the central and regional levels, between technical and social-welfare agencies, between go- 
vernment agencies and non-governmental organizations, initiatives from outside and from within the community. Government agencies that have social competence carry out data collection and identification of community perceptions, control of resource assets, and models of socio-economic activities but the results are not followed up towards community assistance. The data base is not used to make changes in the way people think, behave and act in new settlements.

Affirmation of the social approach in the normalization project of rivers, lakes and reservoirs in the Jakarta area is important because the area is the location of settlements and economic resources of citizens that have been going on for decades. Not only in Jakarta, several studies in other cities show similar things. Based on research in Bangkok, Viratkapan and Perera (2004) stated that the relocation project in Bangkok was needed a special approach because the resettlement project of the city did not only have implications for the loss of population land, but also social implications. Like the case of displacement of residents in the development process of the city of Sarawak, in addition to losing land, the community also loses social structure, social life energy, traditional processes of people's lives, and loss of economic resources (Ahsan and Ahmad 2016).

In his analysis of the development of Jakarta City in a complex setting, Wirutomo (2014) stated the importance of a sociocultural based approach. City development with socio-cultural orientation must touch 3 basic elements, namely structural elements, cultural elements, and processual elements (Wirutomo 2014). Fulfillment of structural elements must be realized in a balanced, accommodating, decisive and effective policy and technical framework. In the context of river normalization and relocation in Jakarta, the fulfillment of structural elements can be seen in the form of the Jakarta Regional Spatial Planning Regulations and Spatial Detail Plans \& Zoning Regulations, as well as the project framework prepared. However, urban development actors are not suf- ficiently behind the rigid and unresponsive policy structure. Structural strength is needed that is able to regulate, limit, and even force community action, but must be responsive, proactive, and not just a fulfillment of procedural administration.

Responsive and proactive policies and frameworks can develop dynamically in a preserved socio-cultural reality. The sociocultural reality that is maintained in urban communities should be seen in the life attitude of urban and community managers who respect and accommodate the values, norms, traditions, awareness, ways of thinking, and ways of acting in urban communities. Such a mindset is in line with urban anthropology which pays attention to the culture of urban society and social institutions seen in daily life, patterns of action, community life, economics, inter-ethnic or inter-ethnic relations, emergence of social groups, hierarchy and stratification social, poverty, and slum settlement (Suparlan 2004).

Urban development that integrates social approaches must also pay attention to and maintain processual elements in the life of society at large. Living processual element is seen from the open and working space of informal interaction and dynamiccreative negotiations in the life of the wider community (Wirutomo 2014). In the context of river normalization and relocation discussed here, this processual element must be seen in the methods and workings of government officials and project apparatus that are open, participatory and persuasive in facing resistance, protest, and answering people's questions. The emergence of acts of violence both from the side of the apparatus and the community and the impatience of government apparatus and project apparatus in dealing with the public showed a weak processual element.

Relocation of urban communities often shows the weakness of processual space that allows all parties to discuss and find solutions to problems persuasively. This is mainly related to the implementation of technical-physical development projects that have implications for the removal of 
land and socio-economic resources of the community. In this connection, it is necessary to look at the research of Viratkapan and Perera (2004) which states that the successful relocation of settlements in Bangkok is determined by a number of internal and external prerequisites. The community must be involved in determining the location and determining compensation. The aspect of community unity, strong leadership, active participation and positive behavior by all parties can determine the success of relocation.

Affirmation of social approaches to normalization and relocation projects are not sufficiently regulated in the policy framework and technical framework but are consistently applied. The social aspect must get special treatment when applied in projects that have strong technical-physical nuances. As stated before, the fulfillment of social aspects within the policy framework and technical framework is not in doubt, but weak in implementation. The social agenda is powerless when dealing with the stages of the project that are included in physical realization. Budget management targets, target budget absorption, and time targets, it is difficult to adapt to social processes in the field that have not been completed. Likewise, with the results of the social assessment in the initial stages, it must be ensured that the results are not only for administrative fulfillment and project procedures but are integrated in project implementation. As stated by Kamil (2014), Indonesia has several village improvement programs in urban areas that are run persuasively. One thing that should be inspired is the arrangement of the Kali Code Yogyakarta village which has a strong social approach.

How to affirm the social approach in a normalization project that coincides with a relocation project? In addition to the technical-physical character inherent in the two projects, the mutually fulfilling relationships between the two projects caused social problems in their implementation. River normalization projects contain specific time targets and management consequences, but execution in the field is determined by the willingness of the community to move and the readiness of new settlements at the destination. In the midst of the crush of the two projects, social problems arise that are difficult to ascertain the completion time target. To overcome this problem, the implementation of a similar project needs special emphasis on the aspects of the social approach, both in the phase of consolidation or initial preparation, the phase of resettlement, and the post-relocation phase. In fact, social processes specifically need to be given space and flexibility in the implementation of the relocation preparation phase and post-relocation phase. So, there is the flexibility of the social approach at the beginning before the physical-technical process, and there is flexibility in the social approach at the end after the technical-physical process. This particular emphasis needs to be done through fulfilling the prerequisites for time, funding, and management resources. So, the social process is not only a complement to physical-technical activities. This is as stated by Viratkapan and Perera (2004), a special approach is needed in handling relocation, both in the phase of consolidation, the phase of resettlement, and the transition phase.

In the perspective of sustainable change, the normalization and relocation program of community settlements cannot be avoided from social contraction in the early stages. There is always a difference in attitude in the form of pros and cons to the idea of change. Differentiation that occur do not need to be faced with repressive methods because it can actually give birth to resistance. Differentiation needs to be dealt with by making adaptive improvements at the apparatus and community level so that new perspectives and new methods of work are created to start new results at new settlement locations. These processes need to be done so that value generalizations occur and born adaptive collective behaviors face new conditions that continue to change (Saifuddin 2005). The government put the river normalization and the relocation of settlements as part of the transformation of the New Jakarta Vision. The transformation of 
the New Jakarta Vision which is interpreted as the future of Jakarta that is "organized, comfortable, livable, and cultured" requires the solidity of conception and implementation at the managerial level, field apparatus and society (Siswanto 2014; Jaweng 2014).

\section{CONCLUSION}

Normalization of the Ciliwung river and relocation of settlements is a choice that must be made to overcome the lack of carrying capacity of the river and the impact of flooding repeatedly. River normalization and relocation projects have been carried out in priority locations based on the magnitude of the impact of the flood. In its implementation, river normalization projects and resettlement relocation projects that have strong technical-physical character are not in line and in tune with the social process for community preparation. The social process requires a longer and dynamic time while the technical-physical process can be targeted and measured. The visible effect is that there is strong urban development practice in the physical-technical approach. On the other hand there is a weak socio-cultural approach that is integrated in people's lives. This condition creates social contraction in the form of citizen rejection, community resistance, and an arrogant and forced approach.

To overcome the gaps that occur, it is necessary to affirm the social approach in the normalization project of the river which coincides with the relocation project. The interrelated relations between the two projects pose social problems in their implementation. Normalization projects contain certain time targets and management consequences, but execution on the field has a social problem that is difficult to ascertain the target time. To overcome this, special emphasis needs to be given to social approaches in the phase of consolidation or initial preparation, the phase of resettlement, and the post-relocation phase. In fact, social processes need to be given space and flexibility in implementation in the preparation phase and post-relocation phase by fulfilling the consequences of financing, time, and management resources.

Theoretically, this research shows the importance of putting a balanced urban development orientation between the character of a physical-technical approach and the character of a socio-cultural approach. Urban development need to be built on a socio-cultural basis as a sub-culture of complex urban societies. The government must build the city above strong structural elements that are seen in policies that are balanced, firm, effective, responsive, open, and participatory. The structural framework must be based on socio-cultural elements that necessitate the integration of values, norms, awareness, perceptions, and ways of thinking of society. The urban development agenda needs to be placed in the framework of long-term and sustainable social change by opening informal spaces of interaction, dynamic and creative negotiation processes.

This research was carried out when the river normalization project took place, the relocation project in the form of new settlement construction, and the transfer of people from the riverbank to the flats as new settlement. The dynamic social situation in the field during the course of this research has become a challenge in the application of research methods. With these considerations, further research is recommended to study the process of adaptation and socioeconomic changes carried out by post-relocation communities.

\section{REFERENCES}

Ahsan, R. and Ahmad, M.H.B.H, 2016. Development, Displacement and Resettlement a Challenge for Social Sustainability: A Study on Mega Development Project (Bakun Dam) In Sarawak. Int'l Journal of Advances in Agricultural E Environmental (IJAAEE), 3(1)Alfitri, F.M., et al. 2017. Sue for Disputes Resolution of Land Conflict in South Sumatera. Komunitas. International Journal of Indonesian Society and Culture, 9 (1), pp. 161-69.

Ali, F. 2014. Terobosan Baru Menyelamatkan dan Menata Ibu Kota" dalam Waduk Pluit: Semangat Membangun Jakarta Baru. Kompas Media Nusantara Jakarta.

Arofah, L. 2015. Developing Research Base Learning in Urban Sociology Class. Jurnal Komunitas, 7(1), oo. 144-56. DOI:10.15294/komunitas.v7i1.3665. 
BPDAS Citarum-Ciliwung. 2009. Laporan Akhir Tahun: Penyusunan Rencana Detil Penanganan Banjir di Wilayah JABODETABEKJUR. Kementerian Kehutanan, Ditjen RLPS, BPDAS Citarum-Ciliwung. Sumber: http://bebas banjir2025. wordpress.com/konsep-pemerintah/bpdas-citarum-ciliwung/. Akses: 4 Agustus 2014.

Bunnell, T., et al. 2013. Urban Development in a Decentralized Indonesia: Two Success Stories? Pacific Affairs. 86.857-876.10.5509/2013864857.

Christanto, J. 2010. Strategi dan Rencana Aksi Pengembangan Pelayanan Sosial Perkotaan dalam Rangka Meningkatkan Daya Dukung di Kawasan di Wilayah DKI Jakarta, Jurnal Ekosains, 2(1)

Creswell, J.W. 2013. Qualitative Inquiry \& Research Design: Choosing Among Five Approaches. Sage Publications.

Creswell, J.W. 2009. Research Design: Qualitative, Quantitative, and Mixed Methods Approaches. Sage Publications, Thousand Oaks California.

Koesoemawati, D.J. 2016. Social Cohesion of Pendalungan Community and Urban Space Integration in Jember. Komunitas, 8(1), pp. 145-54.

Huang, Y., et al. 2018. Social Impacts of Dam-Induced Displacement and Resettlement: A Comparative Case Study in China. Sustainability, 2018, 10, 4018.

Gazali, E. 2014. P(E)Luit Komunikasi Memihat yang Tertinggal" dalam Waduk Pluit: Semangat Membangun Jakarta Baru. Kompas Media Nusantara, Jakarta.

Gilhooly, D. \& Lee, E., 2017. Rethinking Urban Refugee Resettlement: A Case Study of One Karen Community in Rural Georgia, USA. International Migration.55(6) ISSN oo20-7985. doi: 10.1111/imig.12341.

Handoyo, E. and Widyaningrum., N.R. 2015. Relocation as Empowerment: Response, Welfare, and Life Quality of Street Vendors After Relocation. Jurnal Komunitas, 7(1), p. 31-43. doi: http: //dx.doi.org/10.15294/komunitas.v7i1.34xx.

Hans-Dieter E. 1993. Produksi Subsistensi dan Massa Apung Jakarta" dalam Parsudi Suparlan (Editor), Kemiskinan di Perkotaan. Yayasan Obor Indonesia, Jakarta.

Higgins, D.L. and Metzler, M. 2001. Implementing Community-Based Participatory Research Centers in Divers Urban Settings. Journal of Urban Health: Bulleting of the New York Academy of Medicine, 78(3).

Jaweng, R.E. 2014. Kepemimpinan di Era Otonomi Daerah" dalam Waduk Pluit: Semangat Membangun Jakarta Baru. Kompas Media Nusantara, Jakarta.

Kamil, M. 2014. Participatory Design in Kampung Upgrading. https://architectindevelopment.org/ new/php?id.94

Kementeriaan Koordinator Bidang Kesejahteraan Rakyat, 2013. Kemiskinan Ind on es i a:
Perkotaan dan Ulasan Program. Catatan Kebijakan.

Khasan, M., dan Widjanarko, M. 2012. Perilaku Coping Masyarakat Menghadapi Banjir. Jurnal Psikologi Pitutur, 1(2) Lipsky, M., 1980. Street Level Bureaucracy: Dilemmas of the Individual in Public Services. Russel Sage Foundation, New York.

Malo, A.H. 2011. Urban Sustainability and Community Development: Creating Healthy Sustainable Urban Communities. February 2011. Working Paper 2011-03. Department of City and Regional Planning University of California at Berkeley. http://frbsf.org/cdinvestments

Mard, et al. 2018. Nighttime light data reveal how flood protection shapes human proximity to rivers. Science Advances. Sci. Adv. 2018; 4: eaar5779 22 August 2018.

Maring, P. 2015. Culture of control versus the culture of resistance in the case of control of forest. $\mathrm{Ma}$ kara Hubs-Asia, 19(1), p. 27-38. DOI: 10.7454/ mssh.v19i1.3471.

Maring, P., et al. 2015a. Perilaku Kompetitif dan Aksi Ambil Untung di Balik Kemandekan Tata Kelola Bantaran Sungai Ciliwung. Prosiding Seminar Nasional: ISBN: 978-602-702831-9. Cetakan I. Pebruari 2015. Jakarta: PPPMSTISIP Widuri.

Maring, P., et al. 2015b. Social Strategy of Ciliwung River Bank Community. Jurnal Komunitas, 7(1), pp. 102-11. doi:http://dx.doi.org/10.15294/ komunitas.v7i1.3600

Mikmah, S.K., 2010. Studi Sungai Ciliwung Pengabaian Pemerintah Terhadap

Eksistensi Penduduk Pinggir Sungai: Wajah Pengelolaan Sungai di Indonesia,

Jakarta: INFID (International NGO Forum on IndonesianDevelopment). Sumber: konservasidasciliwung.files.wordpress. com /2012/05. Akses: 4 Agustus 2014.

Humaedi, M.A. 2016. Relocation Dilemma: Social and Cultural Challenges in the Relocation of the Victims of Mount Rokatenda Disaster. Komunitas, 8 (2), pp. 221-35 DOI:10.15294/komunitas.v8i2.5461.

Aryantia1, N.Y., et al. 2017. Strategy of Ethnic Identity Negotiations of Javanese Migrants Adolescents in Family Interaction. Komunitas: International Journal of Indonesian Society and Culture, 9 (2), pp. 237-45.

Pemda DKI Jakarta, 2010. Jakarta Urgent Flood Mitigation Project (JUFMP) (Proyek Darutat Pengendalian Banjir Jakarta). Resettlement Policy Framework (RPF) (Kerangka Kebijakan Pemukiman Kembali (KKPK). Pemda DKI Jakarta Republik Indonesia.

Legates, R., et al. 1996. Urban And Community Development. Prepared For The Senate Select Committee On Community Development

Saifuddin, A.F. 2005. Antropologi Kontemporer: Suatu Pengantar Kritis Mengenai Paradigma. Prena- 
da Media, Jakarta.

Safransky, S. 2014. Greening the urban frontier: Race, property, and resettlement in Detroit. Geoforum, 56 , pp. 237-48. http: //dx.doi. org/10.1016/j.geoforum.2014.06.003

Sariffuddin, et al. 2017. Street Vendors Hypergrowth: Consequence of Uncontrolled Urbanization In Semarang City. Komunitas: International Journal of Indonesian Society and Culture, 9 (1),p. 81-91.

Siswanto, A. 2015. Menata Waduk Pluit: Menyongsong Jakarta Baru dalam Waduk Pluit: Semangat Membangun Jakarta Baru. Kompas Media Nusantara, Jakarta.

Suminar, S., et a., 2011. Strategi Penyusunan Pola Tata Komunitas Berbasis Partisipasi Masyarakat Bantaran Sungai Winongso. Jurnal Penelitian BAPPEDA Kota Yogyakarta, No. 6 April 2011, ISSN 1978.0052.

Suparlan, P.2004. Masyarakat dan Kebudayaan Perkotaan: Perspektif Antropologi Perkotaan, Yayasan Pengembangan Kajian Kepolisian.

Taylor, J. L. 1993. "Kampung-kampung Miskin dan
Tempat Pengelompokan Penghuni Liar di Kota-kota Asia Tenggara" dalam Parsudi Suparlan (Editor), Kemiskinan di Perkotaan. Yayasan Obor Indonesia, Jakarta.

Tim Ekspedisi Ciliwung Kompas, 2009. Ekspedisi Ciliwung: Laporan Jurnalistik Kompas Penerbit Kompas, Jakarta.

Vayda, A.P. 1983. Progressive contextualization: Methods for research in human ecology. Human Ecology, 11(3), pp. 265-81.

Viratkapan, V. \& Perera, R. 2004. Slum relocation project in Bangkok: what has contributed to their success or failure? Habitat International. doi: 10.1016/j.habitatint.2004.09.002

Wirutomo, P. 2014. "Penataan Waduk Pluit: Cermin Pembangunan Sosial-Budaya?” dalam Waduk Pluit: Semangat Membangun Jakarta Baru. Kompas Media Nusantara, Jakarta.

World Bank, 2016. http://www.worldbank.org/in/ new/feature/2016; https://m.detik.com/ finance/berita-ekonomi/bank-dunia: Laju Urbanisasi di RI. 